\title{
Democracy, Democratization, and Development in Post-Cold War Africa (1990-2012)
}

\author{
ADRIEN M. RATSIMBAHARISON \\ Department of Social Sciences and Criminal Justice, Benedict College, Columbia, USA.
}

\begin{abstract}
This research project addresses the question of whether democracy would be better than any other political systems to promote development. It attempts to find out whether democracy and democratization have led to a better economic performance in democratic and democratizing countries in Africa. Using data on development from the World Bank and the United Nations Development Program (UNDP) in combination with data on regime characteristics from the Polity IV Project and Freedom House, this research project finds that democracy has weak statistical correlations with development, as indicated by the Human Development Index (HDI) and the gross national income (GNI) per capita of the fifty and so African countries since the end of the Cold War. Nevertheless, this study also finds that democratizing countries seem to have better economic performances than the other African countries.
\end{abstract}

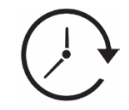

Article History

Received: 17 August 2018 Accepted: 29 December 2018

\section{Keywords}

Africa;

Democracy;

Democratization;

Development.

\section{Introduction}

The relationships between democracy and development have been the subject of countless speculations and research projects for some time. Thus, a few decades ago, some modernization theorists suggested that economic development, through different intervening variables such as the improvement of the education and the emergence of a strong middle class, would eventually lead to democracy in dictatorial regimes. Seymour Lipset was one of the first who made this prediction in the 1950s. In his seminal work on Some Social Requisites of Democracy, he makes the argument that economic prosperity would give rise to a literate middle class, which would espouse liberal values and seek to defend its newly acquired assets through the institution of democratic political systems. However, several historical facts (e.g., the persistence of dictatorship in China, despite its huge economic successes in recent years) and the findings from different studies have proven this prediction to be wrong.

CONTACT Adrien M. Ratsimbaharison $\$ ratsimbaharisona @ benedict.edu $\boldsymbol{9}$ Department of Social Sciences and Criminal Justice, Benedict College, Columbia, USA.

\section{(c) (1)}


Since the triumph of capitalism and democracy at the end of the Cold War, the so-called "democracy promoters" made another argument that democracy along with capitalism would be the best political system to promote rapid economic development in the developing countries. Thus, promoting democracy around the world became one of the major components of the foreign policies of most developed countries, such as the United States.

However, faced with the inability of many democratic countries to solve their own economic problems and the failure of some of them to even stay alive, particularly in Africa, this argument has now become all the more questionable.

This research project deals with the latter argument. It addresses the questions of whether democracy would be better than any other political systems to promote development in Africa and whether democratic and/or democratizing countries have better economic performances than the other African countries.

Following a quick review of the existing literature concerning the relationship between democracy and development, the methodology, including the data, the statistical procedures, and the software used to carry out the analysis will be presented. Next, the findings will be discussed along with the tables and graphs. Finally, the paper will draw the main conclusions and suggest new directions for future researches.

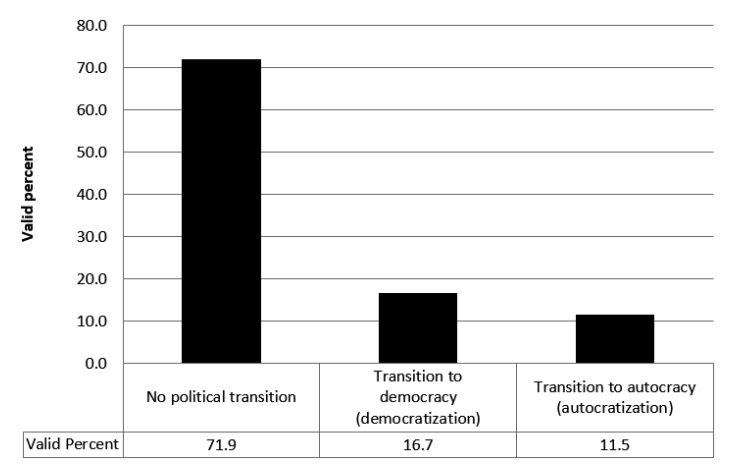

Fig. 1: Political Transitions in Post-Cold War Africa (1989-2012)

\section{Literature Review}

Some scholars are categorical in their findings that democracy does not lead to development (or better economic performance). Among these scholars, Doucouliagos and Ulubasoglu, using "meta-regression analysis to the population of 483 estimates derived from 84 studies on democracy and growth," draw the conclusion that: "democracy does not have a direct impact on economic growth". The findings of Przeworski et al. and Diebolt et al. seem to confirm this hypothesis of no direct effect of democracy on development . Indeed, Przeworski et al. look at the data from 135 countries between 1950 and 1990, and draw the conclusion that economic development does not generate democracies, as in the case of a country like China, but "democracies may be more likely to survive in wealthy societies". In other words, instead of finding the direct effect of democracy on development, they come up with the reverse effect of development on democracy survival. In the same vein, Diebolt et al. confirm the inability of democracy to solve economic problems and suggest that: "democratic poverty trap is found to exist indicating the possibility of persistence of (un)stable democratic equilibria at different levels of democracy".

Among the scholars who support the hypothesis of direct effect of democracy on development, Masaki and van de Walle "find strong evidence that democracy is positively associated with economic growth, and that this 'democratic advantage' is more pronounced for those African countries that have remained democratic for longer periods of time".

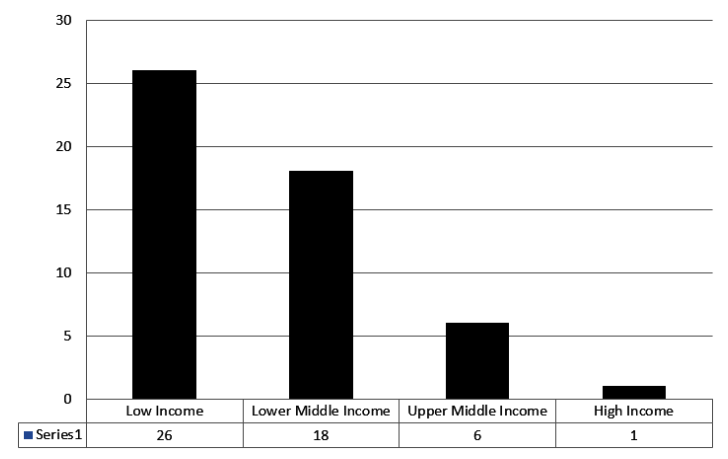

Fig. 2: Classification of the African Economies in 2012 
RATSIMBAHARISON, Current Research Journal of Social Sciences, Vol. 01(2), 60-67 (2018)

Table 1: Frequencies of Regime Types in Post-Cold War Africa (1989-2012)

\begin{tabular}{|c|c|c|c|c|c|c|}
\hline \multirow{2}{*}{$\begin{array}{l}\text { Survey } \\
\text { Edition }\end{array}$} & \multicolumn{2}{|c|}{ Free } & \multicolumn{2}{|c|}{ Partly Free } & \multicolumn{2}{|c|}{ Not Free } \\
\hline & $\begin{array}{l}\text { Number of } \\
\text { Countries }\end{array}$ & Percentage & $\begin{array}{c}\text { Number of } \\
\text { Countries }\end{array}$ & Percentage & $\begin{array}{l}\text { Number of } \\
\text { Countries }\end{array}$ & Percentage \\
\hline 1989 & 2 & 4 & 12 & 26 & 32 & 70 \\
\hline 1990 & 3 & 6 & 11 & 24 & 33 & 70 \\
\hline 1991 & 4 & 8 & 15 & 32 & 28 & 60 \\
\hline 1992 & 8 & 17 & 19 & 40 & 20 & 43 \\
\hline 1993 & 9 & 19 & 23 & 49 & 15 & 32 \\
\hline 1994 & 8 & 17 & 15 & 31 & 25 & 52 \\
\hline 1995 & 8 & 17 & 17 & 35 & 23 & 48 \\
\hline 1996 & 9 & 19 & 19 & 39 & 20 & 42 \\
\hline 1997 & 9 & 19 & 19 & 39 & 20 & 42 \\
\hline 1998 & 9 & 19 & 18 & 37 & 21 & 44 \\
\hline 1999 & 9 & 19 & 20 & 42 & 19 & 39 \\
\hline 2000 & 8 & 17 & 24 & 50 & 16 & 33 \\
\hline 2001 & 9 & 19 & 24 & 50 & 15 & 31 \\
\hline 2002 & 9 & 19 & 25 & 52 & 14 & 29 \\
\hline 2003 & 11 & 23 & 21 & 44 & 16 & 33 \\
\hline 2004 & 11 & 23 & 20 & 42 & 17 & 35 \\
\hline 2005 & 11 & 23 & 21 & 44 & 16 & 33 \\
\hline 2006 & 11 & 23 & 23 & 48 & 14 & 29 \\
\hline 2007 & 11 & 23 & 22 & 46 & 15 & 31 \\
\hline 2008 & 11 & 23 & 23 & 48 & 14 & 29 \\
\hline 2009 & 10 & 21 & 23 & 48 & 15 & 31 \\
\hline 2010 & 9 & 19 & 23 & 48 & 16 & 33 \\
\hline 2011 & 9 & 19 & 22 & 46 & 17 & 35 \\
\hline 2012 & 9 & 18 & 21 & 43 & 19 & 39 \\
\hline
\end{tabular}

Source: Freedom House (2013). Country Status by Region.

Table 2: Frequencies of Political Transitions in Post Cold War Africa (1989-2012)

\begin{tabular}{|c|c|c|c|c|c|}
\hline & & Frequency & Percent & Valid Percent & Cumulative Percent \\
\hline \multirow[t]{4}{*}{ Valid } & No political transition & 876 & 68.9 & 71.9 & 71.9 \\
\hline & $\begin{array}{l}\text { Transition to democracy } \\
\text { (democratization) }\end{array}$ & 203 & 16 & 16.7 & 88.5 \\
\hline & $\begin{array}{l}\text { Transition to autocracy } \\
\text { (autocratization) }\end{array}$ & 140 & 11 & 11.5 & 100 \\
\hline & Total & 1219 & 95.8 & 100 & \\
\hline Missing & System & 53 & 4.2 & & \\
\hline Total & & 1272 & 100 & & \\
\hline
\end{tabular}


However, most of the scholars who also find this direct effect are more nuanced in their assertion. Thus, Carl LeVan makes the argument that "the key factor is not simply the status of the regime as a dictatorship or a democracy, but rather it is the structure of the policy-making process by which different policy demands are included or excluded". In the case of Botswana, which is one the success stories of democracy and development in Africa, Acemoglu et al. draw the following conclusion: "Botswana achieved this rapid development by following orthodox economic policies. How Botswana sustained these policies is a puzzle because typically in Africa, 'good economics' has proved not to be politically feasible. In this Paper, we suggest that good policies were chosen in Botswana because good institutions, which we refer to as institutions of private property, were in place".

\section{Methodology}

This research project uses data on development and economic performance from the World Bank and the United Nations Development Program (UNDP) in combination with data on regime characteristics from the Polity IV Project and Freedom House. These data are analyzed using the statistical software SPSS.

According to the UNDP's people-centered approach, development is understood as follows: "Human development aims to enlarge people's freedoms to do and be what they value and have reason to value

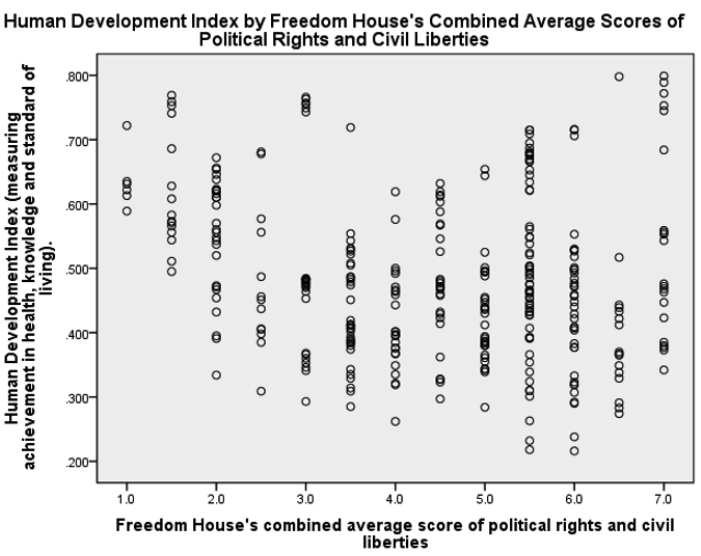

Fig. 3: Scatterplot: Human Development Index by Freedom House's Combined Average Scores of Political Rights and Civil Liberties
[.]. At all levels of development, human development focuses on essential freedoms: enabling people to lead long and healthy lives, to acquire knowledge, to be able to enjoy a decent standard of living and to shape their own lives". In line with this view, development is measured in this study, not only in terms of the traditional World Bank's GNI (gross national income) per capita but also in terms of the UNDP's Human Development Index (HDI).

Following Larry Diamond's dual conception of democracy, the concept of democracy is defined in this study, not only as "a system for arriving at political decisions in which individuals acquire the power to decide by means of a competitive

Table 3: Evolution of the Average GNI per capita in Post Cold-War Africa (1989-2012)

\begin{tabular}{cccc}
\hline Year & $\begin{array}{c}\text { Average GNI } \\
\text { per capita }\end{array}$ & N & $\begin{array}{c}\text { Std. } \\
\text { Deviation }\end{array}$ \\
\hline 1989 & 832.88 & 52 & 1020.262 \\
1990 & 858.43 & 51 & 1085.765 \\
1991 & 910.2 & 49 & 1144.653 \\
1992 & 945.21 & 48 & 1235.693 \\
1993 & 906.12 & 49 & 1231.515 \\
1994 & 877.96 & 49 & 1246.931 \\
1995 & 893.27 & 49 & 1254.513 \\
1996 & 927.55 & 49 & 1303.084 \\
1997 & 952.2 & 50 & 1362.215 \\
1998 & 928 & 50 & 1329.012 \\
1999 & 894.6 & 50 & 1283.416 \\
2000 & 899.6 & 50 & 1303.112 \\
2001 & 907.4 & 50 & 1310.589 \\
2002 & 948.4 & 50 & 1356.653 \\
2003 & 1028 & 50 & 1464.638 \\
2004 & 1186.27 & 51 & 1644.711 \\
2005 & 1474.04 & 52 & 2016.4 \\
2006 & 1669.62 & 52 & 2330.228 \\
2007 & 1910.38 & 52 & 2742.845 \\
2008 & 2195 & 52 & 3136.953 \\
2009 & 2296.92 & 52 & 3328.962 \\
2010 & 2115.88 & 51 & 2828.888 \\
2011 & 2266.27 & 51 & 3119.592 \\
2012 & 2183.33 & 51 & 3109.808 \\
& & & \\
& & &
\end{tabular}

Sources: The World Bank, Gross National Product per Capita, Atlas Method (US current dollar) 
Table 4 - Evolution of the Classification of the African Economies

\begin{tabular}{|c|c|c|c|c|c|}
\hline & $\begin{array}{c}\text { Low } \\
\text { Income }\end{array}$ & $\begin{array}{l}\text { Lower } \\
\text { Middle } \\
\text { Income }\end{array}$ & $\begin{array}{l}\text { Upper } \\
\text { Middle } \\
\text { Income }\end{array}$ & $\begin{array}{c}\text { High } \\
\text { Income }\end{array}$ & Total \\
\hline 1989 & 42 & 8 & 2 & 0 & 52 \\
\hline 1990 & 42 & 7 & 2 & 0 & 51 \\
\hline 1991 & 39 & 8 & 2 & 0 & 49 \\
\hline 1992 & 36 & 10 & 2 & 0 & 48 \\
\hline 1993 & 39 & 8 & 2 & 0 & 49 \\
\hline 1994 & 38 & 9 & 2 & 0 & 49 \\
\hline 1995 & 38 & 10 & 1 & 0 & 49 \\
\hline 1996 & 37 & 10 & 2 & 0 & 49 \\
\hline 1997 & 38 & 10 & 2 & 0 & 50 \\
\hline 1998 & 38 & 11 & 1 & 0 & 50 \\
\hline 1999 & 38 & 11 & 1 & 0 & 50 \\
\hline 2000 & 37 & 12 & 1 & 0 & 50 \\
\hline 2001 & 37 & 12 & 1 & 0 & 50 \\
\hline 2002 & 37 & 11 & 2 & 0 & 50 \\
\hline 2003 & 37 & 10 & 3 & 0 & 50 \\
\hline 2004 & 38 & 9 & 4 & 0 & 51 \\
\hline 2005 & 37 & 8 & 7 & 0 & 52 \\
\hline 2006 & 35 & 10 & 7 & 0 & 52 \\
\hline 2007 & 34 & 11 & 7 & 0 & 52 \\
\hline 2008 & 28 & 15 & 7 & 2 & 52 \\
\hline 2009 & 25 & 18 & 8 & 1 & 52 \\
\hline 2010 & 26 & 16 & 8 & 1 & 51 \\
\hline 2011 & 25 & 18 & 7 & 1 & 51 \\
\hline 2012 & 26 & 18 & 6 & 1 & 51 \\
\hline
\end{tabular}

Sources: The World Bank, Newest country classification (2012)

struggle for the people's vote"(thin side), but also as a system ensuring, among other attributes: "substantial individual freedom of belief, opinion, discussion, speech, publication, broadcast, assembly, demonstration, petition, and (why not the internet"(thick side). Thus, in order to capture the different attributes of democracy, Polity IV's scores of regime characteristics are used alongside Freedom House's scores of political rights and civil liberties.

\section{Findings}

Descriptive Statistics

As shown in Table 1, below, the democratization of Africa really started at the end of the Cold War, when the number of democratic or "free" countries

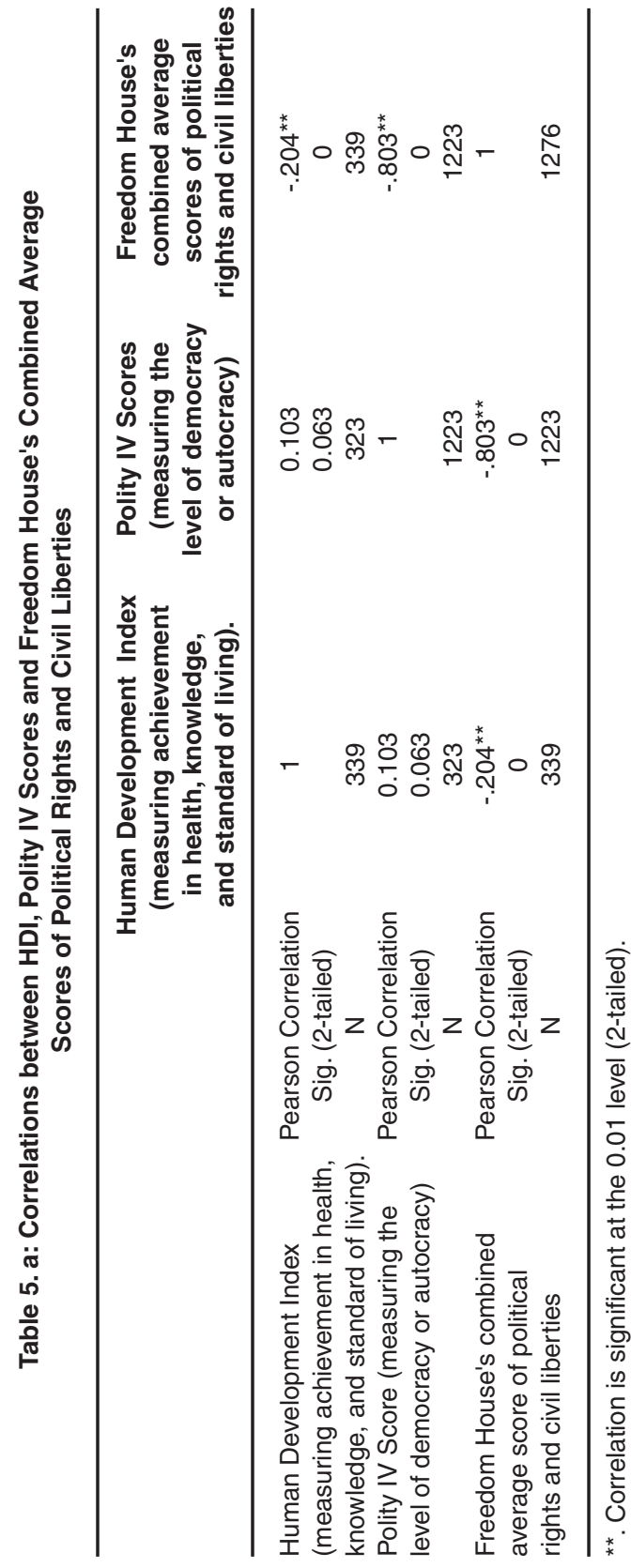

increased from two (2) in 1989 to 9 in 1993. However, since then, the democratization of the continent was stalled, as the number of democracies oscillated around nine (9).

The frequencies of political transitions (either to democracy or autocracy) were relatively low 
compared to that of no transition, as shown in Table 2 and Fig. 1. In other words, Africa has remained relatively stable and autocratic since the end of the Cold War.

With regard to the economic performance, as shown in Table 3, below, the average GNI per capita of the continent increased from $\$ 832.88$ in 1989 to $\$ 2183.33$ in 2012. However, as shown in Fig. 2, the great majority of the African countries (44 out of 51 or $86 \%$ ) are still classified as low income or lower middle income economies; only 7 countries (14\%) are among the upper middle income and high income economies, according to the World Bank.
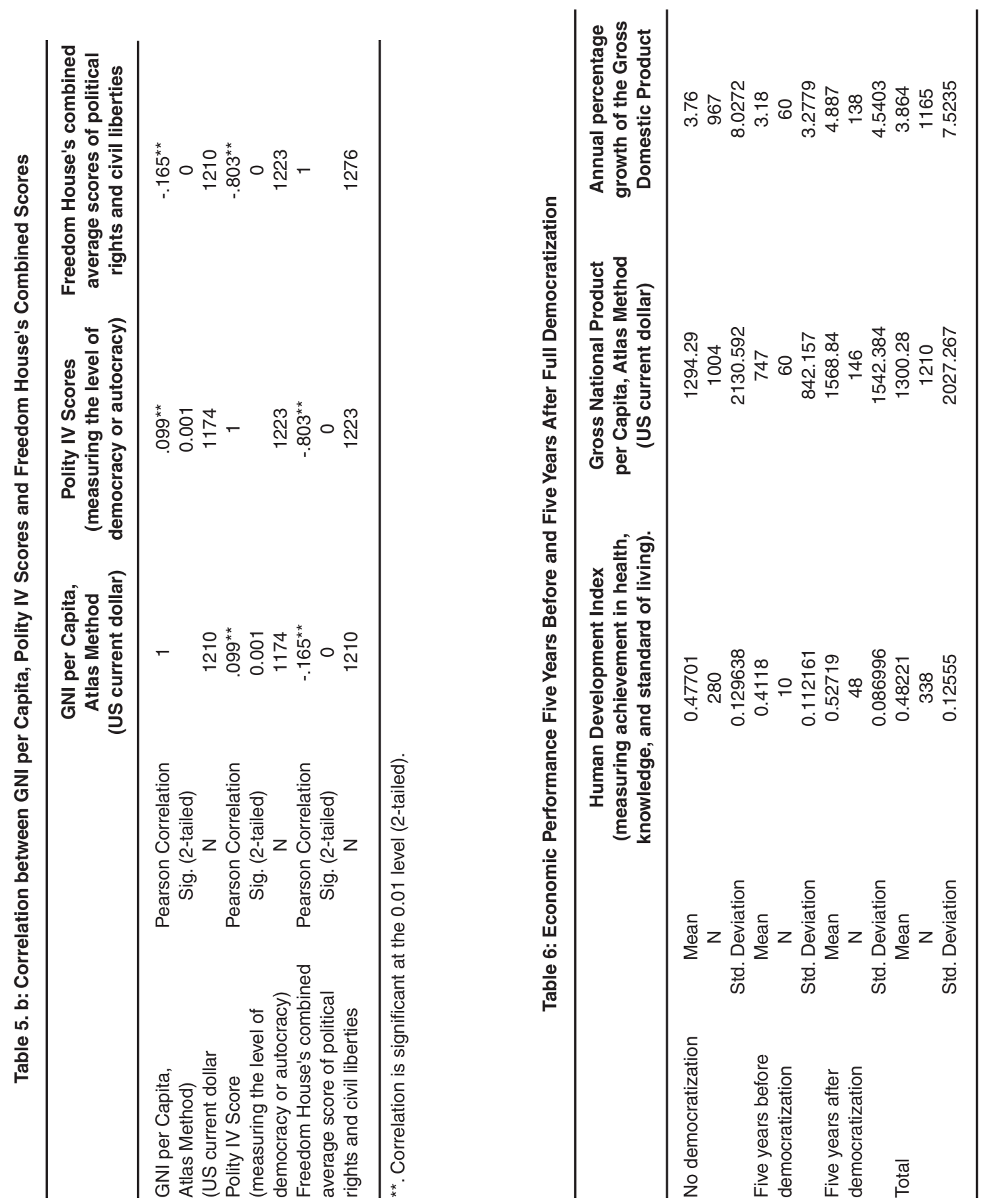
The correlations between Democracy and Development

Tables $5 a$ and $5 b$ show that there are correlations between democracy (as measured in terms of Polity IV scores and Freedom House's combined scores of political rights and civil liberties) and development (as measured in terms of HDI and GNI per capita). These correlations are relatively weak, but they are significant, especially when Freedom House's combined scores are used. It is also worth noting that this weak correlation is demonstrated by Fig 3 Scatterplot: Human Development Index by Freedom House's Combined Average Scores of Political Rights and Civil Liberties.

\section{The Economic Performance of Democratizing Countries}

Table 6 seems to confirm the correlations between democracy and development, as it shows that the countries which have completed full democratizations (i.e., reaching the status of "free countries") are generally performing economically better than those which did not. Indeed, the average HDI of these countries has increased from .4118 (five years before democratization) to .5271 (five years after democratization); and the average GNI per has increased from $\$ 747$ (five years before democratization) to $\$ 1568$ (five years after democratization).

\section{Conclusion}

Using existing data on democracy and democratization, as well as on the economic performance of the African countries since the end of the Cold War
(1990-2012), this research project finds that the correlations between democracy (as measured in terms of Polity IV scores and Freedom House's combined scores of political rights and civil liberties) and development (as measured in terms of HDI and GNI per capita) are generally weak, even though they are statistically significant.

Furthermore, when comparing the performance of democratizing countries with the rest, this study finds that the former perform in general better than the latter. Particularly, the countries which have completed full democratizations (i.e., reaching the status of "free countries") have witnessed their HDI and GNI per capita increased significantly. This better performance may have to do with the developed countries' generous policies toward the democratic and democratizing African countries. Indeed, many developed countries are conditioning their development aid to African countries on the latter's adoption of democratic political systems. In the case of France, for instance, this conditionality was announced by former President Francois Mitterand in his celebrated discours at La Baule.

With regard to the United States of America, since Bill Clinton's presidency, the American markets are opened to democratic and democratizing African countries through the adoption of the African Growth and Opportunity Act (AGOA) in May 2000 (AGOA. info, 2016). Thus, the next step of this research is to find out why democratizing countries are performing better.

\section{References}

1. Lipset, S. M. (1959). Some Social Requisites of Democracy: Economic Development and Political Legitimacy. American Political Science Review, 53(01), 69-105.

2. See particularly, Przeworski, A., Alvarez, M. E., Cheibub, J. A., \& Limongi, F. (2000). Democracy and Development: Political Institutions and Well-Being in the World, 1950-1990. Cambridge, UK: Cambridge University Press.

3. Carson, J. (2013). The Obama Administration's Africa Policy: The First Four Years, 2009-
2013. American Foreign Policy Interests, 35(6), 317-324. https://doi.org/10.1080/108 03920.2013 .855549

4. Doucouliagos, H., \& Ulubaşoğlu, M. A. (2008). Democracy and Economic Growth: A Meta-Analysis. American Journal of Political Science, 52(1), 61-83.

5. Przeworski, A., Alvarez, M. E., Cheibub, J. A., \& Limongi, F. (2000). Democracy and Development: Political Institutions and WellBeing in the World, 1950-1990. Cambridge, UK: Cambridge University Press; and Diebolt, 
C., Mishra, T., Ouattara, B., \& Parhi, M. (2013). Democracy and Economic Growth in an Interdependent World. Review of International Economics, 21(4), 733-749.

6. Przeworski, A., Alvarez, M. E., Cheibub, J. A., \& Limongi, F. (2000). Democracy and Development: Political Institutions and WellBeing in the World, 1950-1990. Cambridge, UK: Cambridge University Press, p. 88.

7. Diebolt, C., Mishra, T., Ouattara, B., \& Parhi, M. (2013). Democracy and Economic Growth in an Interdependent World. Review of International Economics, 21(4), 733-749.

8. Masaki, T. (2014). The Political Economy of Aid Allocation in Africa: Evidence from Zambia. Retrieved from http://takaakimasaki. com/wp-content/uploads/2014/08/Zambia Draft_2014-12-3.pdf, p. 1.

9. LeVan, A. C. (2014). Dictators and Democracy in African Development: The Political Economy of Good Governance in Nigeria. New York, NY: Cambridge University Press,
Summary.

10. Acemoglu, D., Johnson, S., \& Robinson, J. (2002). An African success story: Botswana (Working Paper 01-37). Cambridge, MA: Department of Economics, Massachusetts Institute of Technology. Retrieved from http://dspace.mit.edu/bitstream/handle/172 1. 1/63256/africansuccessst00acem.pdf, p. 1.

11. Alkire, S. (2010). Human Development: Definition, Critiques, and Related Concepts. New York, NY: United Nations Development Programme. Retrieved from http://hdr.undp. org/sites/default/files/hdrp_2010_01.pdf, p. 43.

12. Diamond,L. J. (2008). The Spirit of Democracy: The Struggle to Build Free Societies Throughout the World. New York, New York: Henry Holt and Company, pp. 21-22.

13. Mitterand, F. (1990, June 20). Le discours de La Baule (1990). Retrieved from https:// nsarchive2.gwu.edu/NSAEBB/NSAEBB461/ docs/DOCUMENT\%203\%20-\%20French.pd 